\title{
Conceptualising Party Autonomy in Private International Law
}

\author{
Alex Mills*
}

Introduction

When can parties enter into binding agreements as to the forum in which their disputes will be resolved, or the law that governs their legal relationships? To what extent should parties have the power to make such agreements? To put this another way, to what extent should courts or arbitral tribunals respect and enforce such agreements? These are the principal questions of party autonomy in private international law, which has become an increasingly important and widely accepted part of the global legal landscape. Even non-lawyers are likely to be familiar with (even if they are not likely to read) the clauses in the fine print of contracts that specify the forum and law to govern disputes arising under the contract. Such clauses are often - wrongly - considered merely part of the 'boilerplate' of standard contracting, rather than key terms to be carefully negotiated for a particular relationship. The use of such clauses is ubiquitous, flourishing as an apparent international consensus around at least certain core questions of their validity and effectiveness has emerged and been consolidated. The Hague Convention on Choice of Court Agreements 2005 has, for example, been developed by the main international organisation responsible for harmonising private international law, the Hague Conference on Private International Law. It has come into effect for the Member States of the European Union, Mexico and Singapore, has been signed by the United States, the People's Republic of China, Ukraine, and Montenegro, and is under consideration by other states. ${ }^{1}$ In 2015 the Hague Conference also adopted the Hague Principles on Choice of Law in International Commercial Contracts, a soft law instrument which seeks to influence and promote international adoption of party autonomy in the context of the law applicable to contracts. ${ }^{2}$ Recent European and Chinese regulation in private international law has also extended the scope of party autonomy in choice of law beyond its traditional focus on contract law into other areas of law such as noncontractual obligations, property law, succession, and family law. ${ }^{3}$ Scholars argue that party autonomy has become, or at least is in the process of becoming, close to universal and incontestable as a "unifying principle" of modern private international law, "the one principle in

\footnotetext{
* Professor of Public and Private International Law, Faculty of Laws, University College London, a.mills@,ucl.ac.uk. This article is very closely based on sections of Chapter 1 of Alex Mills, Party Autonomy in Private International Law (Cambridge University Press, 2018), and is published here with the kind permission of Cambridge University Press.

${ }^{1}$ See further Alex Mills, Party Autonomy in Private International Law (Cambridge University Press, 2018), Section 3.1.

2 See further Mills (2018) (n 1), Section 7.2.7.

${ }^{3}$ See further Mills (2018) (n 1), Chapter 8.

${ }^{4}$ Symeon C Symeonides, Codifying Choice of Law Around the World: An International Comparative Analysis (Oxford University Press, 2014), p.346.
} 

RCDIP

conflict of laws that is followed by almost all jurisdictions", 5 or a "rule of customary law". 6 It has even been argued that party autonomy is so central to private international law that the subject should be rethought, so that party autonomy provides its entire foundation. ${ }^{7}$ Party autonomy is so accepted in practice that there is a tendency to suggest, somewhat alarmingly, that it does not require theoretical justification. ${ }^{8}$ Party autonomy is indeed such an omnipresent feature of modern contracting practice as to appear quite banal. It is difficult to imagine an academic argument rejecting party autonomy altogether - it would be considered too far out of step with established practice.

This is not, however, cause to doubt whether an examination and appraisal of party autonomy is necessary - if anything, claims that party autonomy is incontestable should invite us to ask questions and engage in critical analysis. This is at least part of the purpose of the author's recently published book on Party Autonomy in Private International Law (henceforth, 'Party Autonomy $),{ }^{9}$ which analyses the full range of aspects of party autonomy in private international law with a focus on the law of the European Union, the common law, the United States, and international codifications: examining the historical and theoretical foundations of party autonomy and their doctrinal implementation; across both choice of forum and choice of law; including state and non-state forms of law and dispute-resolution (both courts and arbitral tribunals, and state and non-state law); and dealing with contractual and non-contractual disputes. The book does not seek to reject or advocate party autonomy, although such work also of course has its place, ${ }^{10}$ but rather to analyse its coherence as a doctrine. The analysis demonstrates that, despite the apparent consensus that has developed around party autonomy there are numerous controversial questions which still remain unresolved or which are dealt with inconsistently in different jurisdictions. The breadth of scope of the book allows it to address fundamental questions concerning party autonomy as a whole - whether the rules governing party autonomy are consistent with its theoretical and policy justifications, and whether the rules governing different aspects of party autonomy are (or should be) consistent with each other. ${ }^{11}$

\footnotetext{
${ }^{5}$ Matthias Lehmann, 'Liberating the Individual from Battles between States: Justifying Party Autonomy in Conflict of Laws’ (2008) 41 V anderbilt Journal of Transnational Law 381, 385.

${ }^{6}$ Andreas F Lowenfeld, 'International Litigation and the Quest for Reasonableness' (1994) 245 Recueil des Cours 1, 256 ("support of party autonomy is by now so widespread that it can fairly be called a rule of customary law"). See also Peter Nygh, Autonomy in International Contracts (Oxford University Press, 1999), p.45.

7 See eg Sagi Peari, 'The Choice-Based Perspective of Choice-of-Law' (2013) 23 Duke Journal of Comparative \& International Law 477 (in respect of choice of law); Milana Karayanidi, Reassessing the Approach to Jurisdiction in Civil and Commercial Matters: Party Autonomy, Categorical Equality and Sovereignty (2017), PhD thesis, Trinity College Dublin (on file with author) (in respect of jurisdiction).

${ }^{8}$ Horatia Muir Watt, "Party Autonomy" in International Contracts: From the Makings of a Myth to the Requirements of Global Governance' (2010) 6 European Review of Contract Law 250, 252-3, n 5 (criticising the "tendency to consider freedom of choice as so natural as to need no justification").

${ }^{9}$ Mills (2018) (n 1).

${ }^{10}$ It may be noted that Peter Nygh's seminal work Autonomy in International Contracts (1999) (n 6) expressly aimed (at p.vii) "to argue for a further development and extension of the principle of autonomy unhampered by historical notions of territoriality and sovereignty which hitherto sought to restrain it".

${ }^{11}$ Mills (2018) (n 1), Section 1.4.
} 
Party autonomy in private international law is a worthy object of study not only because of its increased popularity, but because it has extremely important - even dramatic - effects. It gives private parties a (limited) power to determine the extent of the jurisdiction of state courts and the scope of application of state law. Private international law has long been understood as being concerned with the allocation of regulatory authority in matters of private law between states, in terms of both institutional authority (jurisdiction) and substantive regulatory authority (applicable law). ${ }^{12}$ This allocation is indeed an important part of global governance, which is also served by rules of jurisdiction in public international law (and by jurisdictional prohibitions such as rules of state immunity). ${ }^{13}$ Importantly, the allocation of regulatory authority must also be understood as a form of regulation, albeit a higher level function - it concerns the regulation of regulation. What is distinctive and even remarkable about party autonomy is that it allows private parties to determine the distribution of private law authority themselves, thus essentially privatising an important allocative function of global governance. Even more significantly, where a non-state forum (arbitration) or non-state law is chosen, the effect can be viewed as a double-privatisation, not just of the allocative function but also of the regulatory function. Private parties may be able to allocate regulatory authority not only between states but also to other private actors, again in terms of both institutional regulatory authority (disputes may be resolved by arbitrators, who are also 'private' actors in the sense that they are often acting under obligations of confidentiality) and substantive regulatory authority (disputes may be resolved through the application of privately generated legal rules).

\section{Perspectives on Party Autonomy}

While party autonomy has become close to ubiquitous and incontestable over the course of the twentieth century, the origins of and justifications for this development, examined elsewhere, ${ }^{14}$ remain relatively obscure. While an academic argument entirely opposing party autonomy would today be difficult to imagine, only a century ago many courts and scholars viewed party autonomy as impossible. Although support for party autonomy has long been a feature of at least some private international law reasoning, many scholars have found it difficult to reconcile such apparent private power with the sovereignty of states. Indeed, party autonomy has never sat comfortably with traditional conceptions of state jurisdiction under public international law. Party autonomy is therefore in the unusual position of being apparently ubiquitous and banal, but also incongruous and exceptional. The theoretical underpinnings of private international law remain underdeveloped - although the various aspects of party autonomy (choice of state and non-state forums, and choice of state and non-state law) have all received significant consideration in academic books and journal articles, this has tended to be fragmented,

\footnotetext{
${ }^{12}$ See further Horatia Muir Watt and Diego P Fernández Arroyo (eds.), Private International Law and Global Governance (Oxford University Press, 2014); Alex Mills, The Confluence of Public and Private International Law (Cambridge University Press, 2009).

${ }^{13}$ See further Alex Mills, 'Rethinking Jurisdiction in International Law' (2014) 84 British Yearbook of International Law 187.
}

${ }^{14}$ Mills (2018) (n 1), Chapter 2. 
particularised, or technical in focus rather than examining questions of underlying principle. This is not to understate the importance of practical work on the drafting and interpretation of such clauses, but simply to note that there has been limited academic engagement with party autonomy as a general phenomenon.

Although this may not be apparent at first glance, the publication of Party Autonomy complements the author's previous book on The Confluence of Public and Private International Law. ${ }^{15}$ That book explored the links between private international law and public international law, examining the extent to which rules of private international law can be considered as manifestations of broader principles of public international law, including the jurisdictional rules which bind states. It dealt with party autonomy, ${ }^{16}$ but inevitably in a limited way given the aims of the book, which focused more on the underlying purpose of private international law and the types of connections that justify the power of a forum or the application of a law in the absence of party choice. Party Autonomy approaches the subject of private international law essentially from the opposite direction. Rather than viewing private international law from the perspective of its relationship with public international law, focused on the rights and powers of states, Party Autonomy focuses on the rights and powers of private parties. ${ }^{17}$ These opposing perspectives are complementary in addressing the range of theoretical foundations of private international law. It is indeed part of the attraction and perhaps even mystique of private international law that it engages such a wide variety of interests, from the powers of states in international law to the rights and interests of disputing private parties.

It is worth noting, however, that party autonomy itself appears radically different depending on the perspective from which it is approached - a point introduced further immediately below, and developed elsewhere. ${ }^{18}$ This is at least in part because private international law functions at two discrete levels. First, it is concerned with the exercise of regulatory authority by one or more states, raising the question of whether that exercise of power is legitimate under international law. Second, it is concerned with the relationship between national courts and two or more disputing private parties, including of course the regulation by the court of the private law relationship between those parties. This raises the question of whether the exercise of power meets standards of fairness to private parties (criteria which can generally be satisfied where those parties have consented to the exercise of power), or whether it balances protecting the interests of the defendant and claimant, alongside third party and public interests. This in turn begs the further question of where these standards of fairness should come from. Different national systems have different conceptions of what is fair or just, and traditional private international law can be understood as engaged instead with the distinct question of how regulatory authority should be allocated (fairly and justly) in the context of a pluralism of

\footnotetext{
${ }^{15}$ Mills (2009) (n 13).

${ }^{16}$ Mills (2009) (n 13), p.291ff.

${ }^{17}$ For a private-centred pespective on public international law jurisdiction, see Mills (2014) (n 14).

18 Mills (2018) (n 1), Chapter 2.
} 
conceptions of 'justice'. ${ }^{19}$ These perspectives are not irreconcilable, but there is an unresolved tension between them in the history and theory of private international law, in which various conceptions of power and fairness have long vied for influence. As discussed below and throughout Party Autonomy, these competing perspectives also explain why party autonomy has at times been viewed as incompatible with the foundations of private international law, and at other times as central to those foundations.

\subsection{Party Autonomy from a State-Sovereigntist Perspective}

Traditionally in international law (at least since the nineteenth century) it is states that are exclusively recognised as possessing sovereignty on the international plane, and state governments who exercise that sovereignty through law, including both private law and private international law. As discussed further below and elsewhere, ${ }^{20}$ the existence of party autonomy has thus sometimes been viewed as a seemingly intractable problem for theorists who have sought to reconcile rules of private international law with public international law - indeed historically some scholars denied the existence of party autonomy precisely because they considered that individuals could not have power over sovereigns, and thus could not have control over the allocation of their regulatory authority. Denying party autonomy has not proven a durable approach in practice, however, and thus some means of reconciliation has long been sought. The solution generally adopted (from this traditional perspective) is to view party autonomy as merely a privilege granted by states and contingently conferred on individuals. Put simply, individuals only have the power to determine which court or law governs their legal relations to the extent that states give them that power (through their domestic law), and states could just as readily take away that power. ${ }^{21}$ In the words of the US Second Restatement of Conflict of Laws:

There is nothing to prevent the forum from employing a choice-of-law rule which provides that, subject to stated exceptions, the law of the state chosen by the parties shall be applied to determine the validity of a contract and the rights created thereby. The law of the state chosen by the parties is applied, not because the parties themselves are legislators, but simply because this is the result demanded by the choice-of-law rule of the forum..$^{22}$

From this perspective, what appears to be an exercise of party autonomy is really no more than parties expressing a preference, stating as a matter of fact which court or law they would prefer. It is states that agree to give effect to that preference in certain circumstances. The justifications for party autonomy, in this model, must be traced to states - looking to the reasons why states support party autonomy, and why they constrain it. This argument does not, therefore, in fact

\footnotetext{
${ }^{19}$ Mills (2009) (n 13), p.3ff.

${ }^{20}$ Mills (2018) (n 1), Chapter 2.

${ }^{21}$ See eg Mo Zhang, 'Party Autonomy and Beyond: An International Perspective of Contractual Choice of Law' (2006) 20 Emory International Law Review 511, 555ff; Nygh (1999) (n 6), p.32ff.

22 Section 187, comment (e).
} 
provide a 'justification' for party autonomy, but more an explanation as to how party autonomy can be adopted - through the private international law of states. There is, in this view, a superficial quality to the 'autonomy' exercised by private parties, because it is entirely contingent on the largess of states, although even from this perspective the fact that states have almost universally chosen to confer this power is significant in and of itself.

The legitimacy of an exercise of party autonomy, viewed from this perspective, derives from the legitimacy of the exercise of state power through which it is recognised. As already noted, this raises the question of whether party autonomy is compatible with public international law constraints on state power, which are principally set out in the international law on jurisdiction. If a state court exercises jurisdiction or applies its law in civil proceedings based purely on consent by the parties, this is obviously difficult to reconcile with the traditional public international law requirement that jurisdiction must be justified by a substantial objective connection, typically of territoriality or nationality. ${ }^{23}$ Faced with this argument, three alternative responses have generally been presented. First, rejecting the idea that private international law is about the allocation of regulatory authority between states - denying any connection between public and private international law, thus rejecting the application of public international law jurisdictional rules to civil disputes, leaving them unrestricted except under national law. The difficulty with this response is that it would leave the exercise of civil jurisdiction unlimited also in the absence of party autonomy, which is inconsistent with state practice and normatively undesirable as it would greatly increase the risk of parallel proceedings and conflicting judgments and fail to recognise the regulatory significance of private and procedural law. ${ }^{24}$ Second, making (unrealistic) arguments against party autonomy, a response taken perhaps most famously under the First Restatement of Conflict of Laws in the United States. As examined further elsewhere, ${ }^{25}$ this response was inconsistent with the predominant practice of the courts even at the time, and is now simply untenable. Third, accepting party autonomy, but limiting the choice of the parties to those states that have an objective connection which would justify the exercise of jurisdiction under public international law. Practice in some states has tended to limit party autonomy on these grounds, ${ }^{26}$ thus viewing it as a rule of selection (where multiple states are connected to a legal relationship, determining which of them gets to exercise regulatory authority) rather than a rule through which the parties can themselves confer such authority. However, the practice of most states does not restrict party autonomy in this way.

None of these approaches is, therefore, entirely satisfactory, and a fourth approach may be suggested as a preferable alternative - to accept that the rules on public international law are applicable, but to reformulate our account of the rules so that it is consistent with party

\footnotetext{
${ }^{23}$ See further Mills (2014) (n 14).

${ }^{24}$ See eg the submissions of the European Commission and (jointly) the United Kingdom and the Netherlands in Kiobel v Royal Dutch Petroleum, 133 S.Ct. 1659 (2013), discussed further in Mills (2014) (n 14), p.225ff. See further Alex Mills, 'Private Interests and Private Law Regulation in Public International Law Jurisdiction', in P Cragl et al, Oxford Handbook on Jurisdiction in International Law (Oxford University Press, forthcoming 2019).

${ }^{25}$ Mills (2018) (n 1), Section 2.2.2.

${ }^{26}$ Mills (2018) (n 1), Sections 3.4 and 7.3.
} 
autonomy. This requires accepting that party agreement is itself a connecting factor that justifies the exercise of jurisdiction by a state. A court may hear a case or apply a law based purely on the agreement between the parties, with no objective connecting factors (connections of territoriality or nationality) to justify the national exercise of jurisdiction as a matter of public international law. However precisely this argument is formulated, it is difficult to contest in light of the widespread practice that states have agreed that the recognition of an exercise of party autonomy is consistent with the applicable principles of public international law. ${ }^{27}$

\subsection{Party Autonomy from a Party-Sovereigntist Perspective}

From a contrasting private party-centred perspective, it might be argued that private parties have an inherent autonomy, particularly where they act beyond the boundaries of a single legal order, and it is states that are recognising that underlying reality in accepting the freedom of private parties to choose a forum or law. From this more 'radical' perspective, party autonomy is a direct challenge to the predominance of state sovereignty, perhaps even suggesting instead the coexistence of 'individual sovereignty' alongside the sovereignty of the state. Horatia Muir Watt, noting the dominance of the state-sovereigntist approach discussed above, has argued that the "representation of party freedom as being subordinate to state authority appears to have survived both the demise of the liberal state in the domestic sphere and the decline of the Westphalian model in international relations" ${ }^{28}$ - but that survival is increasingly coming under challenge, as "party autonomy has evidently ceased to imply subordination of private actors to state authority, but actually reverses this relationship". ${ }^{29}$ An analogy might be drawn here with developments in international human rights law, and the contested question of whether such rights are merely the contingent creations of states, or a new foundation of international law itself (beyond the Westphalian model), operating as a fundamental and permanent constraint on state sovereignty. This may be more than an analogy - some have argued that the foundations of party autonomy in private international law should lie in a 'human right' of personal freedom, which is itself prior to the state, particularly since the sovereignty of the state may be viewed as deriving from an exercise of individual autonomy through the form of a social contract. ${ }^{30}$ This argument is, of course, much less persuasive when it comes to legal entities like companies, for whom the idea of innate legal (let alone 'human') rights would appear paradoxical, since they are creations of state law. This may, however, overstate the role of law, in particular of any national law in regulating a transnational enterprise, and the limited reality of legal personality in a corporate group formed of a fluid constellation of different national legal persons. Another

\footnotetext{
${ }^{27}$ As noted above, it has been argued that party autonomy has itself attained the status of a rule of customary international law: Lowenfeld (1994) (n 6), p.256; Nygh (1999) (n 6), p.45. See further Mills (2019) (n 25).

28 Muir Watt (2010) (n 8), p.258.

${ }^{29}$ Ibid.

${ }^{30}$ See eg Jürgen Basedow 'The Law of Open Societies - Private Ordering and Public Regulation of International Relations' (2013) 360 Recueil des Cours 9, 182 ('If State sovereignty for its part can be attributed to the will of the individual, the exercise of this will as regards the applicable law in a conflict-of-laws scenario cannot be attacked as an infringement on the sovereignty of the State.”). See further discussion in Mills (2018) (n 1), Section 2.3.1.
} 
version of this argument is to see private parties as exercising a form of law-making authority when they make a contract - a posture famously adopted in French law ${ }^{31}$ - and thus as themselves 'sovereign' in a sense that encompasses at least private international law party autonomy. The French expression for party autonomy, autonomie de la volonté, pointedly suggests such a foundational role for the will of the parties.

From this perspective, when rules of private international law accept party autonomy, they are merely recognising the autonomy of private parties, rather than making a contingent choice to give effect to party preferences. Under this perspective, the justifications for party autonomy and the reasons for its constraint should focus on private parties themselves. As discussed further elsewhere, ${ }^{32}$ the legitimacy of an exercise of party autonomy derives (in this approach, somehow) directly from the agreement of the parties, rather than from its recognition in national law - the fact of the agreement itself justifies its effectiveness, and makes its effectiveness just. As a result, private international law rules do not only involve mediating between the principles of justice embodied in systems of national law, but also invoke principles of justice that are not embodied in national law. In the words of Matthias Lehmann:

Party autonomy can only be justified if one ignores the state relations that have so far been the focus of the classic theory. One needs to accept that the parties are the center of the conflicts problem. They are allowed to choose the applicable law because it is their dispute that is in question. ${ }^{33}$

Those examining the question from a state-sovereigntist perspective might respond to this claim by arguing that the agreement between the parties is in turn derivative from national law, as it is national law that confers upon it the status of a contract. However, in its strongest form, the argument from a party-sovereigntist perspective rejects the contention that to be effective an agreement must be conferred the status of contract under national law, positing either a contract without law, or simply that an agreement alone is sufficient. The context in which this argument is most often made is in relation to arbitration (and it is no coincidence that it is most associated with French law and scholars given the intellectual traditions noted above), ${ }^{34}$ where the claim is commonly (but still controversially) made that the authority of an arbitral tribunal derives solely from the agreement between the parties, and not from any national legal order. The agreement itself is, under this approach, considered to be a source of rights and obligations. ${ }^{35}$

This perspective is even more difficult to reconcile with traditional principles of international law than the state-sovereigntist perspective discussed above, because it requires recognising that individuals are themselves a source of normative authority - that international jurisdiction is not merely a matter of the rights and powers of states. An argument can be made, however, that this

\footnotetext{
${ }^{31}$ French Civil Code 2016, Art.1103 (previously Art.1134); see Nygh (1999) (n 6), p.7 and p.35ff.

32 Mills (2018) (n 1), Section 2.3.1.

${ }^{33}$ Lehmann (2008) (n 5), p.415.

34 See further Mills (2018) (n 1), Section 6.2.

35 Discussed further below and in Mills (2018) (n 1), Chapter 6.
} 
is indeed the case, through the increased recognition of individuals as subjects of international law. ${ }^{36}$ In the striking words of the Court of Appeal of England and Wales:

a fundamental change has occurred within public international law. The traditional view of public international law as a system of law merely regulating the conduct of states among themselves on the international plane has long been discarded. In its place has emerged a system which includes the regulation of human rights by international law, a system of which individuals are rightly considered to be subjects. ${ }^{37}$

If an acknowledgement is made of an 'individual sovereignty' that is balanced against that of the state, the widespread recognition of party autonomy - even viewed as deriving from the parties themselves rather than national law - can be considered to be compatible with norms of public international law jurisdiction. ${ }^{38}$ The apparent incompatibility arises only as a result of traditional and now arguably outmoded conceptions of public international law jurisdiction, which conceive of jurisdiction as purely a matter of (territorial or nationality-based) state rights and powers. Party autonomy provides an argument for an evolution in these ideas of jurisdiction, to encapsulate the idea of jurisdiction as a matter of individual right. Another way of expressing this idea is that the right to be subject to jurisdiction only in accordance with traditional international law limitations (based on connections of territoriality or nationality) is a right that may be waived, not only by states, but seemingly by individuals themselves. However it is expressed, this idea suggests that the adoption of party autonomy in private international law is a reflection of broader developments in international ordering, under which international law is no longer just the law between states, but is more broadly conceived as the global law of humanity. ${ }^{39}$ As Hans Van Loon has perceptively observed:

Where the nation-State is no longer its sole anchor space, private international law must transcend its traditional boundaries, and, adapting its methodologies while preserving its integrity, orient itself towards the idea of an emerging global community. ${ }^{40}$

\footnotetext{
${ }^{36}$ See generally eg Mills (2014) (n 14).

${ }^{37}$ Belhaj v. Straw [2014] EWCA Civ 1394, [115].

38 The deference to party autonomy in private international law was long ago described as reflecting "the sovereign will of the parties" by Judge Bustamente in his Separate Opinion in the Serbian Loans Case, France v Yugoslavia (1929) PCIJ Ser A, No 20, Judgment 14, p.53. Note also the recognition of the affinity between international norms and private international law rules on party autonomy in the Principles on 'The Autonomy of the Parties in International Contracts Between Private Persons or Entities', International Law Association, adopted in Basel 1991. Available at www.idi-iil.org/app/uploads/2017/06/1991 bal 02 en.pdf.

${ }^{39}$ See eg Ruti G. Teitel, Humanity's Law (Oxford University Press, 2011); Anne Peters, 'Humanity as the A and $\Omega$ of Sovereignty' (2009) 20 European Journal of International Law 513; Fernando R Tesón, 'The Kantian Theory of International Law' (1992) 92 Columbia Law Review 53; Louis B Sohn, 'The New International Law: Protection of the Rights of Individuals Rather Than States' (1982) 32 American University Law Review 1.
}

${ }^{40}$ J H A Van Loon, 'The Global Horizon of Private International Law' (2016) 380 Recueil des Cours 9, 45. 


\subsection{Congruence or Competition}

This analysis is developed further in Party Autonomy ${ }^{41}$ - for present purposes, the key point is simply that party autonomy in private international law can be viewed from the radically different perspectives explored above. A central complexity of party autonomy in private international law is that these explanations appear to co-exist in an uneasy truce. On the one hand, party autonomy is indeed evidently the product of national legislative processes (albeit based in some cases on international codification), through which limited rights are conferred on private parties. Part of the reality of how party autonomy is given effect is through national law, even if this does not engage with the question of why national legal orders would permit such a choice. On the other hand, multinational parties engaging in cross-border activity may not view their choices of court, arbitral tribunal or law as a product of any particular national legal order, but rather as an exercise of an autonomous power, under which their private agreement designates the applicable legal order. While these different approaches may be in tension, they are not necessarily so states may for a variety of reasons (explored throughout Party Autonomy) be interested in facilitating the autonomy of private parties, rather than constraining it. However, as discussed further elsewhere, ${ }^{42}$ these different approaches suggest an alignment with different theoretical foundations for party autonomy. As a result, there are likely to be boundaries to this coincidence of interests, reflected in controversies over the legal limits on party autonomy.

These contrasting perspectives run throughout the different aspects of party autonomy, but perhaps the most obvious area where they have come into direct conflict is choice of non-state dispute resolution and law. There is widespread agreement among states - principally in the form of the New York Convention on the Recognition and Enforcement of Foreign Arbitral Awards 1958 - that parties should be free to grant exclusive jurisdiction over their private disputes to non-state methods of dispute resolution, such as arbitral tribunals, to the (at least partial) exclusion of state judicial jurisdiction. This development is subject to two contrasting and incompatible readings, each of which is both widely adopted and heavily contested. The first is that it simply reflects the acceptance by states of arbitration as a form of alternative dispute resolution, backed up by state courts, but lacking any normative power of its own. The second is the more radical proposition that it implies the acceptance by states of a non-state form of ordering, alongside and competing with national courts - that arbitral tribunals are privately constituted courts, sometimes even applying privately constituted (non-state) private law. This revolutionary idea would certainly represent a further challenge to traditional conceptions of jurisdiction, recognising individual party freedom to choose not just between state laws or adjudicative bodies, but beyond them, through the recognition of private (non-state) legal forms of ordering, or of legal pluralism beyond the state. ${ }^{43}$ It would thus also be a serious challenge to the idea that jurisdiction in public international law is only concerned with the powers of states, as it would involve accepting not just individual jurisdictional power, but also jurisdictional power created and conferred by individuals on private institutions - not just privatisation of the regulatory

\footnotetext{
${ }^{41}$ Mills (2018) (n 1), Chapter 2.

${ }^{42}$ Mills (2018) (n 1), Section 2.3.

${ }^{43}$ See further discussion in Mills (2018) (n 1), Sections 6.2 and 10.1.
} 

RCDIP

function of private international law, but also privatisation of the regulatory functions of substantive private law and national courts. Whether this is indeed taking place, or has already taken place, remains one of the great issues of the international legal order, as part of the delicate and constantly contested balance between public and private forms of power. 